\title{
IBADAH DAN KESEHATAN DALAM PERSPEKTIF ISLAM DAN SAINS
}

\author{
Warto \\ warto@umt.ac.id \\ (Dosen Fakultas Agama Islam Universitas Muhammadiyah Tangerang)
}

\begin{abstract}
Abstrak;
Ibadah tidak hanya memiliki fungsi ritual an sick. Selain sebagai kewajiban, kebutuhan dan sarana membangun koneksi dengan Sang Pencipta, ibadah memiliki banyak manfaat lain bagi manusia. Berdasarkan alasan ini penelitian secara ilmiah dilakukan terhadap praktek ibadah. Hasil penelitian menunjukkan bahwa pelaksanaan ibadah dapat mendatangkan berbagai manfaat dan pengaruh positif bagi pelaksananya. Secara faktual, sains modern telah membuktikan bahwa ibadah bermanfaat untuk terapi kesehatan dan obat jasmani maupun rohani.
\end{abstract}

Kata Kunci: Ibadah, rohani, jasmani, sains, kesehatan

\section{A. Pendahuluan}

Ibadah memiliki peranan penting bagi manusia. Ia memiliki banyak fungsi dan manfaat. Diantaranya, ibadah menjadi misi dan tujuan hidup manusia. Karena alasan inilah Allah menciptakan manusia. "Dan Aku tidak menciptakan jin dan manusia, melainkan supaya mereka menyembah-Ku. ${ }^{1}$ Ibadah juga merupakan kebutuhan bagi manusia. Tepatnya ibadah merupakan kebutuhan dimensi ruhiyah manusia. Oleh sebab itu, semua agama mengajarkan praktek ibadah kepada para pemeluknya. Baik itu agama samawi maupun agama ardhi. Kebutuhan ibadah ini dijelaskan di dalam al-Quran surat alBaqarah ayat 21. Allah SWT berfirman, "Hai manusia, sembahlah Tuhanmu Yang telah menciptakanmu dan orang-orang yang sebelummu, agar kamu bertakwa". Ayat ini menggunakan redaksi "wahai manusia”. Ini artinya ibadah adalah kebutuhan seluruh manusia.

Dalam sepanjang sejarah, ibadah merupakan problem utama bagi manusia dan menjadi misi utama diutusnya para

${ }^{1}$ QS. 51. Adz-Dzariyat: 56 rasul. Ibadah menjadi problem bagi manusia maksudnya adalah kebanyakan manusia enggan beribadah, maka dari itu Allah mengutus para rasul untuk menuntun manusia kembali ke jalan fitrah yaitu beribadah kepada Allah SWT. "Dan sesungguhnya Kami telah mengutus rasul pada tiap-tiap umat (untuk menyerukan), "Sembahlah Allah (saja), dan jauhilah Thaghut itu", maka di antara umat itu ada orang-orang yang diberi petunjuk oleh Allah dan ada pula di antaranya orangorang yang telah pasti kesesatan baginya. Maka berjalanlah kamu di muka bumi dan perhatikanlah bagaimana kesudahan orang-orang yang mendustakan (rasulrasul)". ${ }^{2}$ Penjelasan ayat ini diperkuat dengan kisah-kisah para nabi. Disebutkan pada kisah nabi Nuh AS dan kaumnya, Hud AS, Shaleh AS, Syuaib AS dan rasulrasul lainnya. Kisah ini disebutkan Allah dalam surat al-A'raf ayat $[59,65,73$, dan 85]. Juga disebutkan dalam surat Hud ayat [50, 61 dan 84]. Allah SWT berfirman, "Sesungguhnya Kami telah mengutus Nuh kepada kaumnya lalu ia berkata, "Wahai

${ }^{2}$ QS. 16. An-Nahl: 36. 
kaumku sembahlah Allah, sekali-kali tak ada Tuhan bagimu selain-Nya." Sesungguhnya (kalau kamu tidak menyembah Allah), aku takut kamu akan ditimpa azab hari yang besar (kiamat). Uraian ini menegaskan bahwa ibadah merupakan bagian penting yang tidak bisa dilepaskan dari kehidupan manusia.

Di sisi lainnya, ibadah merupakan salah satu sarana seorang hamba untuk mendekatkan diri dan membangun koneksi dengan penciptanya. Hal ini perlu dilakukan karena dalam hidup ini manusia membutuhkan Allah Yang Maha Pencipta, Yang Maha Besar, Yang Maha Kuasa, Yang Maha Adil dan Yang Maha Bijaksana. Tuhan yang memberikan rezeki kepada manusia, memberi kehidupan, memberi nyawa dan segalanya. Maka manusia membutuhkan tumpuan di dalam kehidupan yang penuh ketidakpastian. "Dan tiada seorang pun yang dapat mengetahui (dengan pasti) apa yang akan diusahakannya besok. Dan tiada seorang pun yang dapat mengetahui di bumi mana dia akan mati... ${ }^{3}$ Tanpa membangun koneksi dengan Penciptanya manusia akan hidup dalam kehampaan, kesempitan, kesulitan, kesengsaraan, kesedihan, kepanikan dan seterusnya. "Dan barang siapa berpaling dari mengingat-Ku, maka sesungguhnya baginya penghidupan yang sempit, dan Kami akan menghimpunkannya pada hari kiamat dalam keadaan buta". ${ }^{4}$ Sebaliknya, orang-orang yang selalu menguatkan ibadah dan koneksinya kepada Allah diberikan kehidupan yang lebih baik. Inilah arti penting ibadah bagi manusia.

Dengan ibadah maka manusia akan mendapatkan banyak kebaikan dalam hidupnya. Diantara kebaikan yang diperoleh orang-orang yang menjaga ibadah, ia akan diberikan rezeki yang

\footnotetext{
${ }^{3}$ QS. 31. Luqman: 34

${ }^{4}$ QS. 20. Thaha: 124
}

melimpah. Dalam hadits al-Qudsi Allah berfirman, "Wahai anak Adam, persembahkanlah waktu untuk beribadah kepadaku, maka aku akan memenuhi hatimu dengan kekayaan dan aku akan memenuhi tanganmu dengan rezeki, janganlah menjauh dari-Ku, maka aku akan memenuhi hatimu dengan kefakiran dan aku penuhi tanganmu dengan kesibukan". Orang yang menjaga ibadah juga diberikan kesehatan. ${ }^{6}$ Orang yang beribadah diberikan ketenangan hidup. Rasulullah bersabda, "Dan telah dijadikan shalat itu sebagai penentram jiwaku” HR. An-Nasai. Dalam riwayat Ahmad, dan Abu Dawud, Khudzaifah bin Yaman mengatakan, "Oleh karena itu, jika rasulullah menjumpai sesuatu yang menghawatirkan beliau segera shalat". Dengan ibadah pula dihapus dosa-dosa manusia. Tak ada manusia yang tak berdosa dalam kehidupan ini. Hanya saja tingkatannya berbeda beda. Ada dosa besar, sedang dan kecil. Dengan kenyataan ini maka penting untuk membersihkan diri manusia dari dosa-dosa baik yang disengaja ataupun tidak. Sebab jika dosadosa ini dibiarkan akan berakibat buruk pada diri manusia. Ia akan mengotori jiwanya/ruhaninya. Berpengaruh pada kejiwaan dan mentalnya dan bahkan

${ }^{5}$ Imam At-Tirmidzi, al-Jami' ash-Shahih Sunan At-Tirmidzi, Beirut, Dar Ihya' at-Turats alArabi, Juz 4, hal. 642

${ }^{6}$ Rasulullah SAW bersabda, "Hendaklah kalian mengerjakan sholat malam, karena itu merupakan kebiasaan orang sholeh sebelum kalian ... dan mencegah penyakit dari badan". (HR. Ahmad, Tirmidzi, Hakim). Rasulullah SAW juga bersabda, "Obatilah orang sakit diantara kalian dengan sedekah..." Dalam hadits lain Nabi SAW juga bersabda, "Berpuasalah maka kamu akan sehat".

${ }^{7}$ Allah SWT berfirman, "Orang-orang yang beriman dan hati mereka menjadi tenteram dengan mengingat Allah. Ingatlah, hanya dengan mengingat Allah-lah hati menjadi tenteram". QS. 13. Ar-Ra'du: 28 
kesuluruhan hidupnya. Manusia terlahir suci dan disaat meninggal juga harus dalam keadaan suci, sementara dosa selalu bertambah setiap saat, dimana saja, kapan saja dan keadaan apa saja. Maka kemudian Allah mensyariatkan ibadah kepada manusia, diantara target dari ibadah itu adalah untuk menghapuskan dosa dan perbuatan buruk yang dilakukan manusia selama hidupnya. Pengaruh dosa itu sendiri bagi kejiwaan dan kehidupan manusia telah dijelaskan rasulullah bahwa dosa itu menodai kebersihan hati. Sementara kejernian hati dibutuhkan dalam mempertimbangkan perbuatan sebelum dikerjakan. Melalui ibadah dosa dalam hati dibersihkan sehingga berkilau seperti semula. Sebaliknya jika tidak dosa dalam hati tak dibersihkan maka nodanya makin tebal dan terus bertambah dengan bertambahnya dosa yang dilakukannya. Lalu terkunci dalam kegelapan dosa. Dengan ibadah manusia akan memperoleh kehidupan yang indah, damai, tentram, bahagia dan dijauhkan dari keburukan dalam hidupnya.

\section{B. Pembahasan}

Ibadah tidak hanya memiliki fungsi ritual semata tapi memiliki banyak manfaat bagi manusia. Ibadah selain sebagai kewajiban, kebutuhan dan sarana membangun koneksi dengan Sang Pencipta juga memiliki banyak manfaat lain yang sangat penting bagi manusia. Berdasarkan hal ini banyak penelitian ilmiah dilakukan.

\section{Ibadah dan Pengobatan dalam Tinjauan Islam dan Sains}

Bagi sebagian besar orang Barat, ibadah termasuk sesuatu yang tidak rasional. Sehingga bagi mereka ibadah bukanlah sesuatu yang ilmiah, yang bisa dibuktikan kebenarannya berdasarkan data dan fakta. Namun berdasarkan banyak penelitian yang dilakukan ditemukan bahwa ibadah memiliki pengaruh yang signifikan terhadap kesehatan dan pengobatan. Sementara kenyataan ini telah diketahui sejak zaman Nabi SAW.

Prof. Dr. M. Amin Syukur, dalam bukunya "Zikir Menyembuhkan Kankerku” mengatakan bahwa pada kenyataannya penyakit itu ada dua macam, yaitu fisik dan psikis. Keduanya bersumber dari pikiran atau perasaan dan dari perut. ${ }^{8}$ Hal ini sesuai pernyataan Al-Harits bin Kildah, seorang tabib Arab yang mengatakan, "Perut adalah sumber penyakit dan diet adalah obat segala penyakit". 9 Baik fisik maupun psikis keduanya saling mempengaruhi. Sakit fisik bisa berpengaruh kepada sakit psikis, dan sebaliknya sakit psikis menyebabkan sakit fisik. Dengan demikian pengobatan penyakit juga dilakukan dengan dua cara; secara medis dengan obat dan konsultasi dokter sebagai ikhtiyar zhahir atau fisik, dan secara metafisik melalui dzikir, doa dan ibadah. Penggabungan antara medis dan dzikir, dalam istilah Prof. Dr. M. Amin Syukur disebut pengobatan min-plus; sikap aktif (berobat) dan sekaligus pasif (sikap pasrah). ${ }^{10}$

Bagi sebagian orang terapi metafisik berupa dzikir, doa dan ibadah sering dianggap tidak rasional. Namun dalam kenyataannya jalan ini justru paling ampuh dalam bidang pengobatan. Jika lebih jauh menelusuri teks-teks agama baik itu alQuran maupun sunnah nabi, maka akan kita jumpai banyak cara-cara pengobatan dan terapi secara metafisik melalui dzikir, doa dan ibadah. Bahkan dalam pengobatan modern dan canggih cara ini juga ditempuh. Misalkan saja puasa. Sering dianjurkan para dokter sebagai terapi

${ }^{8}$ M. Amin Syukur, MA, Zikir Menyembuhkan Kankerku, penerbit Hikmah, hal. 104

${ }^{9}$ Al-Qadhi 'Iyadh, Ikmal al-Muallim Syarh Shahih Muslim, tanpa keterangan, Juz 1 hal 127

${ }^{10} \mathrm{M}$. Amin Syukur, MA, Zikir Menyembuhkan Kankerku, penerbit Hikmah, hal. 104 
kesehatan bahkan saat pasien menjalani operasi. Pengobatan dua model baik secara medis atau metafisik sama-sama dibutuhkan bagi pasien untuk mempercepat proses kesembuhan.

Pengobatan secara metafisik dengan dzikir, doa dan ibadah telah banyak dipraktekkan pada masa Nabi Muhammad SAW. Suatu ketika Nabi Saw, pernah melakukan ruqyah, memohon perlindungan kepada Allah, dengan cara beliau mengusapkan tangan kanannya dan berdoa.

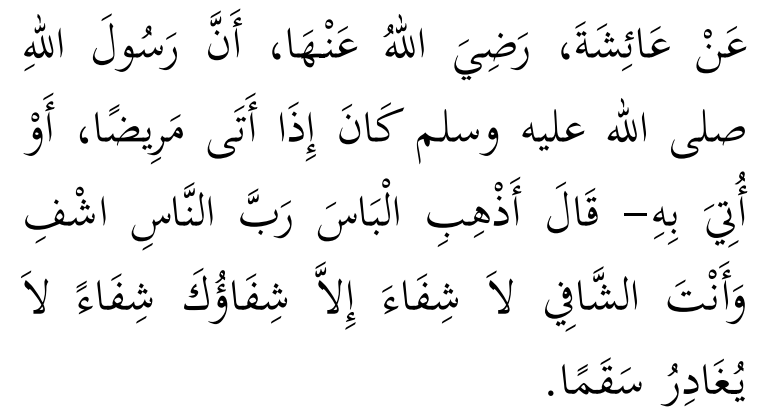

Diriwayatkan dari Aisyah RA, bahwa rasulullah SAW apabila mendatangi orang sakit, atau didatangi orang sakit beliau berdoa, "Hilangkanlah penyakit Wahai Rabb manusia, sembuhkankanlah, karena sungguh Engkau Zat Maha Penyembuh, tiada kesembuhan selain kesembuhan darimu, yaitu kesembuhan yang tidak menyisakan sakit. ${ }^{11}$

Suatu ketika Nabi Saw. mendapat keluhan sakit, karena luka di anggota badannya. Beliau pun berkata dengan menunjukkan jari tangannya. Beliau mengangkatnya seraya memanjatkan doa,

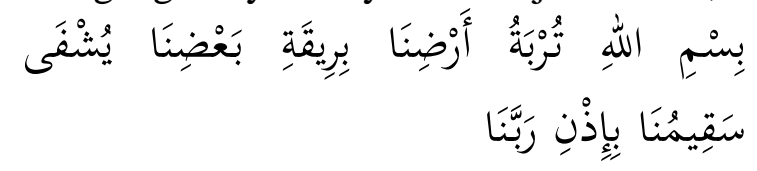

"Dengan nama Allah, dengan debu bumi kami dan sebagian liur kami, disembuhkan penyakit kami dengan seijin Rabb kami". ${ }^{12}$

\footnotetext{
${ }^{11}$ Imam al-Bukhari, Al-Jami' Ash-Shahih, Kairo: Dar Asy-Sya'b, Juz 7, hal. 157

'Imam al-Bukhari, Al-Jami' Ash-Shahih, Kairo: Dar Asy-Sya'b, Juz 7, hal. 172
}

Ini adalah beberapa contoh pengobatan metafisik melalui dzikir dan doa, dalam upaya untuk mendapatkan kesembuhan dari penyakit yang bahkan penyakit itu terkadang karena akibat dosa yang dilakukan manusia. Lalu apakah terapi metafisik melalui dzikir, doa dan ibadah efektif dan dikabulkan?

Agar cara pengobatan ini efektif dan dikabulkan Allah, maka menurut Prof. Dr. Amin Syukur ada beberapa syarat yang harus penuhi. Pertama; Orang yang melakukan pengobatan harus suci dari dosa dan najis. Seorang Badui pernah datang dengan pakaian kotor dan tidak beralaskan kaki, seraya berdoa kepada Allah Swt., "Ya Tuhan, Ya Tuhan berilah Aku ini dan itu..." Akan tetapi, kondisi orang Badui itu tidak bersih dan suci, baik pakaian, makanan, dan minuman. Ia juga banyak memakan dan menggunakan barang haram. "Maka bagaimana doanya akan dikabulkan oleh Allah Swt.," kata Rasulullah Saw. ${ }^{13}$ Kedua; Setiap kali berzikir dan berdoa hendaknya menyebut nama Allah Swt., lalu diikuti dengan membaca shalawat kepada Nabi saw. dengan penuh kekhusyukan. Ketiga; Sebelum berdoa, terlebih dahulu melaksanakan shalat (baik wajib maupun sunah) secara khusyu. Keempat; Sikap mental kita penuh dengan keyakinan. Kelima; Perihal posisi badan (menghadap ke arah kiblat), waktu, dan tempat berdoa. Waktu yang mustajabah untuk berdoa: waktu sore menjelang terbenamnya matahari, waktu diantara dua khutbah Jumat, sesudah shalat fardhu. Tempat yang mustajabah untuk berdoa: di masjid, di Masjidil Haram, di Multazam, di Maqam Ibrahim, di Raudhah (tempat di antara rumah dan mimbar Nabi SAW). Keenam; Konsisten antara ucapan dan tindakan. Jangan mengakui cinta nabi-Nya,

\footnotetext{
${ }^{13}$ Imam al-Muslim, Al-Jami' Ash-Shahih Shahih Muslim, Beirut: Dar al-Jail dan Dar al-Afaq al-Jadidah, Juz 3, hal. 85
} 
tetapi meninggalkan sunahnya. Mengakui setan sebagai musuh, tetapi mengikuti ajakannya. Menyatakan bahwa mati itu benar, tetapi tidak mau mempersiapkannya. Menyatakan takut neraka-Nya, tetapi merelakan diri memasukinya. Menyatakan cinta surga-Nya, tetapi tidak mau melakukan perintah-Nya. Sibukkan dengan cela dan aib orang lain, tetapi melupakan cela dan aib diri sendiri. Memakan nikmatNya, tetapi tidak mau mensyukurinya. Mengubur mayat, tetapi kamu tidak mau mengambil pelajaran daripadanya. ${ }^{14}$

\section{Wudhu dalam Tinjaun Kesehatan dan Sains}

Berwudhu merupakan salah satu ritual yang lazimnya dilakukan sebelum melaksanakan ibadah shalat. Bahkan ritual wudhu ini oleh banyak ulama tidak dibatasi penggunaannya untuk melaksanakan shalat saja, tapi untuk tujuan lain. Seperti yang dilakukan Imam Malik. Sebelum meriwayatkan atau menyampaikan hadits, Imam Malik selalu berwudhu terlebih dahulu. Sebagian ulama bahkan ada yang menjadikan wudhu sebagai bagian yang tidak terpisahkan dari hidupnya. Mereka senantiasa menjaga wudhu sepanjang waktu (daimul wudhu'). Sebagaimana yang dicontohkan imam Syafii. Allah SWT berfirman,

"Hai orang-orang yang beriman, apabila kamu hendak mengerjakan salat, maka basuhlah mukamu dan tanganmu sampai dengan siku, dan sapulah kepalamu dan (basuh) kakimu sampai dengan kedua mata kaki... ${ }^{15}$

Ibnu Al-Qayyim berkata, "Diantara keindahan Syariah adalah mensyariatkan wudhu pada anggota badan yang nampak dan terbuka. Wajah adalah anggota badan yang pertama kali paling berhak untuk

\footnotetext{
${ }^{14}$ M. Amin Syukur, Zikir Menyembuhkan Kankerku, penerbit Hikmah, hal. 111

${ }^{15}$ QS. 5. Al-Maaidah: 6.
}

dibasuh dengan air wudhu. Hal ini karena kebersihan dan pancaran wajah adalah tanda kebersihan hati. Baru setelah itu kedua tangan. Keduanya adalah alat yang digunakan untuk makan, mengambil dan memukul, maka tangan merupakan anggota badan yang lebih berhak dibersihkan dan diseterilkan kedua setelah wajah. Pada saat kepala adalah tempat berkumpulnya panca indra, bagian tubuh paling tinggi, dan paling dimuliakan, maka ia lebih berhak untuk dibersihkan, namun jika disyariatkan membasuhnya niscaya akan memberatkan dan menyulitkan maka disyariatkan untuk diusap baik keseluruhan atau sebagian sebagai ganti dari dibasuh, sehingga lebih meringankan. Kaki digunakan untuk berjalan di atas tanah dan bersinggungan langsung dengan kotoran, tidak seperti anggota badan yang lain, maka ia lebih berhak untuk dicuci. Inilah kelebihan anggota badan yang dibasuh dalam wudhu dibandingkan yang lainnya. Ini pemahaman wudhu secara zhahir.16

Adapun secara maknawi, anggota badan ini yang secara langsung digunakan oleh seorang hamba untuk melakukan maksiat. Demikian juga anggota badan ini yang digunakan untuk melakukan taat. Tangan digunakan untuk memukul, kaki untuk melangkah, mata untuk melihat, telinga untuk mendengar, lisan untuk berbicara, maka membasuh anggota tersebut adalah bentuk melaksanakan perintah, sakaligus ibadah, untuk membersihkan kotoran-kotoran maksiat dan dosa yang dilakukan anggota badan tersebut.

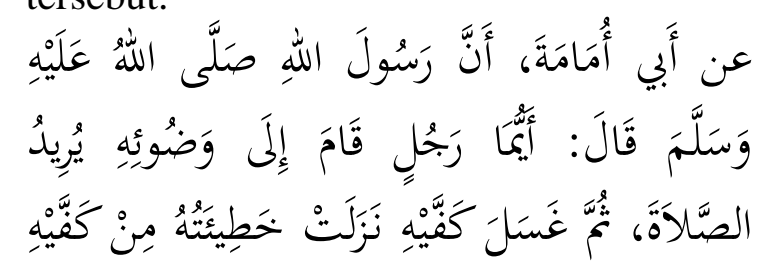

16 Jauziyah, Abu Abdullah Ibn Al-Qayyim, I'lam Al-Muwaqi'in 'an Rabb Al-'Alamin, Dar AlJail, Beirut, 1973, Juz 2, hal 96 


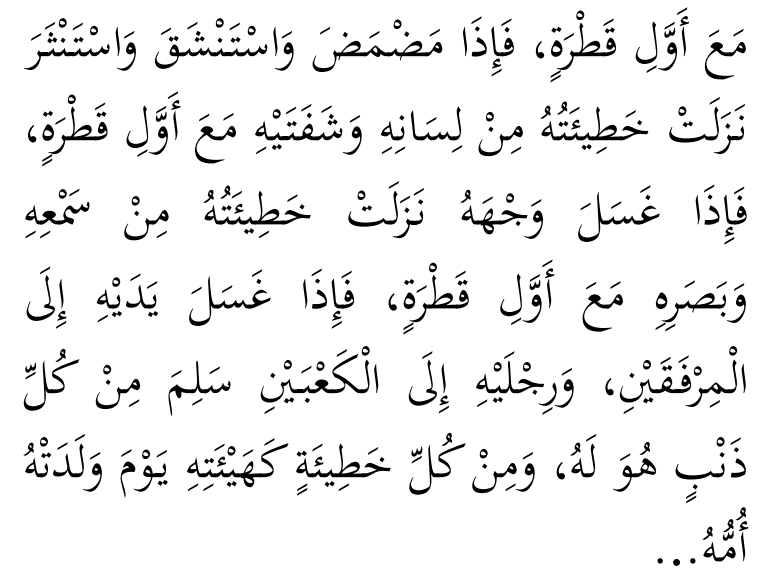

Dari Abu Umamah bahwa rasulullah SAW bersabda, "Siapapun orangnya yang berdiri menuju air wudhunya karena ingin shalat lalu ia mencuci kedua telapak tangannya maka lunturlah dosa-dosanya dari tangannya bersama tetesan air yang pertama. Ketika ia berkurmur dan menghirup air hidung dan mengeluarkannya maka rontoklah dosanya dari lisannya dan bibirnya bersamaan dengan tetesan air yang pertama. Jika ia membasuh wajahnya maka rontoklah dosanya dari pendengaran dan penglihatannya bersamaan dengan tetesan air yang pertama. Ketika ia membasuh tangannya sampai siku, membasuh kedua kaki sampai mata kaki maka selamatlah ia dari setiap dosa yang ada padanya dan dari setiap dosa seperti hari ia dilahirkan ibunya... ${ }^{17}$

Abdush-Shamad, Muhammad Kamil, menuturkan dalam bukunya "Mukjizat Ilmiah dalam Al-Quran" bahwa ilmu pengetahuan modern menetapkan bahwa wudhu mampu meminimalisir timbulnya virus-virus kanker, yang disebabkan oleh faktor-faktor proses kimiawi. Sebab, dengan wudhu orang bisa terhindar dari terjangkitnya unsur kimiawi sebelum terjadinya akresi (gabungan unsur yang terpisah) yang menimbulkan infiltrasi (proses perembesan) dari kulit luar ke dalam tubuh. Misalnya, pekerja yang selalu

\footnotetext{
${ }^{17}$ Imam Ahmad bin Hanbal, Musnad alImam Ahmad bin Hanbal, Kairo: Muassasah alQurthubah, Juz 5, hal. 263
}

berkecimpung mengenai perminyakan yang mengandung unsur-unsur kimiawi, maka sebagian besar mereka mengidap penyakit kanker kulit.

Adapun kiat untuk menjaga agar tidak terjangkit penyakit itu, mereka harus menjauhkan diri dari unsur-unsur kimia dari kulit luar. Apalagi, pada daerah organorgan tubuh vang sensitif terkontaminasi (tercampuri unsur-unsur kimia). Dari sinilah, tampak hikmah wudhu.

Berwudhu lima kali dalam sehari bisa menjamin lenyapnya unsur-unsur kimia dari kulit luar. Juga menghilangkan mikroba dan parasit yang keluar dari lobang hidung, rongga mulut dan lobang telinga. ${ }^{18}$ Sekaligus mampu mencegah terjadinya akresi dari apa-apa yang memperlambat atas sel-sel kulit yang membutuhkan waktu cukup lama untuk memperbarui perubahan-perubahan kanker.

Pancaran sinar matahari, lebih-lebih pantulan sinar ultraviolet, memiliki pengaruh yang sangat efektif dalam menciptakan kanker kulit. Namun, sinar yang berpotensi besar menimbulkan kanker kulit itu, hanya akan menimpa pada organ-organ tubuh luar. Dengan berulang kalinya orang berwudhu, maka kulit luar bisa terjamin selalu basah. Karenanya, selsel lapisan dalam kulit bisa terlindungi dari sengatan sinar yang membahayakan.

Dari pantauan data statistik diketahui bahwa kanker kulit dengan berbagai macam variasinya, lebih sering menimpa kaum pria dalam pergumulan masyarakat Barat dan Amerika Serikat serta Australia. Pasalnya, mereka bukan negara muslim (atau, mayoritas penduduknya muslim) yang penduduknya sering berwudhu. Juga karena faktor suhu panas yang sangat menyengat di wilayah negara-negara tersebut. ${ }^{19}$

${ }^{18}$ Adnan Asy-Syarif, Min Ilmi Al-Thib AlQurani, 2001, Beirut, Lebanon, Dar Al-Ilmy li AlMalayin, Hal. 242

${ }^{19}$ Hilmi Habib al-Khauly, Al-Slaam Wa AlWiqaayatu Min Ba'dhi As-Sarathaani, dimuat Majalah Al-'Arabie, Januari, 1985. 
Fakta ini mempertegas sisi positif pengaruh wudhu, yang seperti senjata penjaga bagi seorang muslim dari kejamnva penyakit-penyakit terlaknat itu. Salah seorang pakar kedokteran dalam wacana pengobatan preventif di Universitas Kairo, Dr. Abdul Wahid, berkata, "Kulit bisa memberi fungsi yang amat signifikan bagi tubuh manusia, yakni berfungsi sebagai jalan pengeluaran keringat yang mengandung unsur-unsur lemak dan kadar garam. Jika terjadi penguapan dalam tubuh, maka menyisakan kadar garam dan akan terjadi akresi atas kulit serta pori-pori kelenjar keringat menjadi tertutup karena tersendatnya pengeluaran keringat yang tidak normal. Sementara itu, adanya kotoran-kotoran di atas kulit akan menambah tumbuh suburnya penyakit-penyakit kulit.

Dari uraian di atas, menunjukkan urgensitasnya wudhu dengan membasuh muka, membasuh kedua tangan, berkumur (membersihkan mulut) serta organ-organ tubuh luar yang lain, guna menghindari diri dari kotoran-kotoran dan debu.

Berdasarkan penemuan ilmu medis mutakhir, wudhu memiliki dampak yang sangat baik dalam menjaga sakit gigi dan gusi. Menggosok gigi dan berkumur dengan air adalah hal yang amat penting, bahkan acapkali para dokter memberi resep seperti itu. Hal ini berfaedah untuk menjauhkan diri dari penyakit-penyakit yang mewabah melalui alat pemapasan, seperti radang selaput dan juga penyakitpenyakit saluran pemapasan. Uraian di atas, hanyalah beberapa poin faedah wudhu dalam perspektif pengetahuan modem. ${ }^{20}$

${ }^{20}$ Abdush-Shamad, Muhammad Kamil, Mukjizat Ilmiah dalam Al-Quran, Jakarta, Akbar Media Eka Sarana, 2002, hal. 297.

\section{Shalat Malam dalam Tinjauan Kesehatan dan Sains}

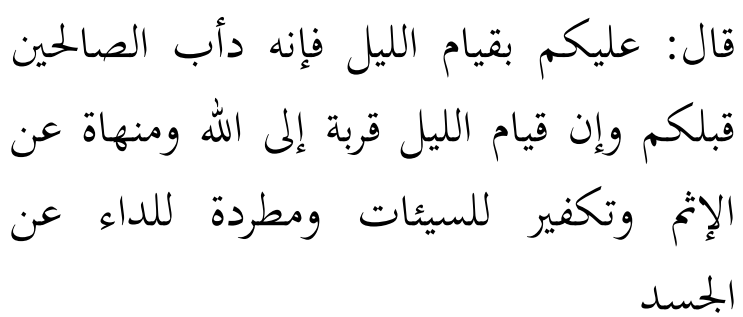

Rasulullah SAW bersabda, "Hendaklah kalian mengerjakan sholat malam, karena itu merupakan kebiasaan orang sholeh sebelum kalian, mendekatkan diri kepada Allah, mencegah dari perbuatan dosa, menghapus keburukan, dan mencegah penyakit dari badan". ${ }^{21}$

Sesuai dengan hadits di atas Ibnu AlQayyim, menegaskan bahwa shalat dapat mencegah perbuatan dosa, mengobati penyakit hati, menghilangkan penyakit jasmani, mendatangkan rezeki dan menyehatkan badan serta jiwa". 22 Dari penjelasan hadist dan apa yang dikatakan Ibnu al-Qayyim menguatkan bahwa shalat malam dapat mencegah atau menolak penyakit dari badan. Ini artinya badan orang yang rajin shalat malam memiliki daya tangkal terbaik terhadap penyakit.

Banyak argumen dan penemuan ilmiah memperkuat kebenaran hadits ini. Di dalam al-Quran dapat dijumpai penjelasan mengenai manfaat shalat, bahwa shalat itu untuk mengingat Allah, "Dan dirikanlah shalat untuk mengingatku",23 atau shalat itu sarana berhubungan dan berkomunikasi dengan Allah SWT. Rasulullah SAW bersabda, "Sesungguhnya apabila salah seorang dari kalian itu berdiri dalam shalatnya, maka sesungguhnya ia sedang

${ }^{21}$ Imam At-Tirmidzi, al-Jami' ash-Shahih Sunan At-Tirmidzi, Beirut, Dar Ihya' at-Turats alArabi, Juz 5, hal. 552

${ }^{22}$ Hasan bin Ahmad Hammam, et al, Terapi Dengan Ibadah, Kartasura Solo, 2015, PT. Aqwam Media Profetika, hal. 183.

${ }^{23}$ QS. 20. Thaha: 14 
berbisik/bercerita kepada rabbnya,24 Bahwa dengan shalat itu manusia memperbaiki komunikasi dan hubungan dengan Allah sang Pencipta. Manusia tidak boleh putus koneksinya dengan Allah yang Maha Kuasa. Keterputusan manusia dalam koneksi dengan Allah akan mendatangkan banyak ke-mudharat-an dan keadaan bahaya dalam hidup manusia. Allah SWT berfirman, "Barangsiapa yang berpaling dari mengingatku maka sesungguhnya baginya penghidupan yang sempit". 25 Penghidupan yang sempit adalah nama lain dari depresi, yang diantara sebabnya adalah karena ia tidak terbiasa mengadukan beban dan kepenatan hidupnya. Beban kehidupan manusia membuat manusia mengalami depresi. Dengan shalat manusia bisa mengadukan keluh kesah kepada penciptanya. Bahkan ia bebas menangis mengeluarkan segala beban dan sesak dihatinya, dan hanya kepada-Nya lah manusia boleh berkeluh kesah. Sehingga dengan shalat seorang hamba telah mengkonsultasikan kehidupannya kepada penciptanya. Inilah sebabnya orang yang rajin shalat mendapatkan ketenangan dan ketentraman dalam kehidupannya. Dr. Rose Hilferding, seorang psikolog di rumah sakit Boston, Amerika serikat berkata, "Terapi yang paling manjur untuk mengatasi depresi dan kegelisahan adalah si pasien mengadukan segala kepenatannya kepada orang yang paling ia percaya". ${ }^{26}$ Adakah yang lebih bisa dipercaya dalam kehidupan ini selain Allah yang maha kuasa?

Dengan memperbaiki koneksinya dengan Allah maka manusia akan memperoleh jaminan-jaminan, dan

\footnotetext{
${ }^{24}$ Muhammad bin Ismail bin Ibrahim bin AlMughirah Al-Bukhari, Al-Jami' Ash-Shahih, Kairo, Dar Asy-Sya'b, Cet. I, 1987, Juz 1, hal. 112.

${ }^{25}$ QS. Thaha; 124

${ }^{26}$ Hasan bin Ahmad Hammam, et al, Terapi Dengan Ibadah, Kartasura Solo, 2015, PT. Aqwam Media Profetika, hal. 228
}

perlindungan dalam kehidupannya, dengan demikian ia akan memperoleh ketenangan dalam jiwanya. Allah berfirman, "Ingatlah kalian kepada-Ku maka Aku akan mengingat kalian". 27 Dan Nabi SAW bersabda, "Kenalilah Allah pada waktu luang maka Allah akan mengenalimu saat susah". ${ }^{28}$ Nabi juga bersabda, "Jagalah (komunikasimu) dengan Allah, maka Allah akan menjagamu". ${ }^{29}$ Orang yang menjaga koneksi dan komunikasinya dengan Allah maka Allah juga menjamin rezekinya, "Wahai anak Adam, beribadahlah sepenuhnya kepada-Ku, pasti Aku akan memenuhi dadamu dengan kecukupan dan menutupi kefakiranmu. Jika engkau tidak melakukannya, Aku akan memenuhi dadamu dengan kesibukan dan tidak menutupi kefakiranmu".30 Shalat juga dikatakan sebagai penerang dalam diri manusia, "Shalat adalah cahaya". 31 Shalat adalah penolong, "Dan carilah pertolongan dengan sabar dan shalat”. Juga shalat adalah penenang jiwa, "Orangorang yang beriman dan hati mereka menjadi tenteram dengan mengingat Allah. Ingatlah, hanya dengan mengingati Allahlah hati menjadi tenteram. ${ }^{32}$

Dalam studi kontemporer banyak ilmuan menemukan manfaat shalat ini. Imam Ahmad dalam kitab "Al-Musnad" menyebutkan sebuah hadits yang berkaitan dengan hal ini, Nabi SAW, beliau

${ }^{27}$ QS. 02. Al-baqarah: 152
${ }^{28}$ Imam al-Hakim An-Naisaburi, alMustadrak 'ala Ash-Shahihaini, Beirut: dar AlKutub Al-Ilmiyah, 1990/1411, juz 3, hal. 623.

${ }^{29}$ Imam At-Tirmidzi, al-Jami' ash-Shahih Sunan At-Tirmidzi, Beirut, Dar Ihya' at-Turats alArabi, Juz 4, hal. 667

${ }^{30}$ Muhammad bin Isa Abu Isa at-Tirmidzi As-Silmi, Al-Jami' Ash-Shahih Sunan At-Tirmidzi, Dar Ihya' At-turats Al-Araby, Beirut, Juz 4, hal. 462 .

${ }^{31}$ Imam Al-Baihaqi, Sunan Al-Baihaqi AlKubra, Makkah al-Mukarramah: Maktabah Dar alBaar, 1994/1414, juz 1, hal. 42

${ }^{32}$ (QS. 13. Ar-Ra'd: 28) 
bersabda, "Wahai Bilal, Istirahatkan kita dengan shalat".33 Dan Nabi SAW, bersabda, "Dan telah dijadikan penentram jiwaku dengan shalat”. 34 Dalam syarah "Umdatul Ahkam" Jibrin menjelaskan bahwa orang yang melaksanakan shalat dengan tenang "sakinah" maka ia akan mendapatkan kesenangan, kegembiraan dan rileks, inilah yang bisa membuat hati dan badan mendapatkan kenyamanan istirahat. $^{35}$

Ketenangan jiwa inilah yang memperbaiki sistem kekebalan tubuh manusia. Meningkatkan imunitas dan antibodi. Berbagai riset dan kajian yang dilakukan dilembaga riset islam di Amerika menyatakan bahwa ketenangan jiwa yang dihasilkan dengan shalat berdampak positif terhadap sistem kekebalan tubuh (antibodi). Sehingga dapat mempercepat proses penyembuhan khususnya dalam beberapa penyakit yang disebabkan kelainan antibodi, seperti radang persendian, reumatik dan penyakit lupus. Riset ini menerangkan bahwa standar kesembuhan dari penyakit terjadi lebih cepat bagi para pasien yang senantiasa rutin melaksanakan shalat. Karena shalat dapat mengisi hati mereka dengan keimanan, optimisme, ketenangan jiwa, dan ketentraman. Dengan demikian sistem kekebalan tubuh akan lebih aktif dan bertambah kuat dalam melindungi tubuh. $^{36}$ Ketenangan jiwa ini akan jauh lebih baik diperoleh ketika shalat malam.

\footnotetext{
${ }^{33}$ Hanbali, Ahmad bin Hanbal Abu Abdullah, Musnad Al-Imam Ahmad bin Hanbal, Kairo, Muassasah Qurthubah, Juz 5, hal. 364

${ }^{34}$ Hanbali, Ahmad bin Hanbal Abu Abdullah, Musnad Al-Imam Ahmad bin Hanbal, Kairo, Muassasah Qurthubah, Juz 3, hal.285

${ }^{35}$ Abdullah bin Abdurrahman Al-Jibrin, Syarah Umdatul Ahkam, tanpa keterangan, Juz.9, hal. 4

${ }^{36}$ Hasan bin Ahmad Hammam, et al, Terapi Dengan Ibadah, Kartasura Solo, 2015, PT. Aqwam Media Profetika, hal. 235.
}

Inilah sebabnya dikatakan oleh rasulullah bahwa shalat malam itu menolak penyakit.

\section{Sedekah dan Kesehatan dalam Tinjauan Agama dan Sains

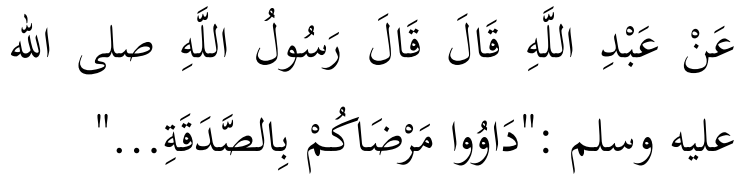

Al-Aswad bin Yazid meriwayatkan Dari Abdullah ra, Ia berkata, Rasulullah SAW bersabda, "Obatilah orang sakit di antara kalian dengan sedekah...,

Hadits di atas adalah nash yang menyebutkan sedekah merupakan salah satu media pengobatan dan penyembuhan atas izin Allah. Kata-kata di atas diungkapkan oleh orang yang ma'shum, yang tidak berbicara berdasarkan hawa nafsu. Ibnu al-Qayyim berkata, "Setiap dokter yang tidak mengobati pasiennya dengan memeriksa hati, kebaikan, kekuatan ruhani, dan tidak menguatkan itu semua dengan sedekah, berbuat kebaikan dan kebajikan serta kembali kepada Allah dan hari akhir, berarti ia bukan dokter sejati. Akan tetapi, seseorang yang baru belajar".

Sedekah bisa menghilangkan penyakit setelah terjangkit dan akan mencegahnya sebelum terjangkit. Ulama fikih dan dokter mengatakan bahwa tindakan pencegahan lebih mudah daripada pengobatan. Karena itu, mencegah sesuatu sebelum terjadi jauh lebih mudah daripada menghilangkannya setelah terjadi. Pencegahan lebih berguna daripada pengobatan untuk menghilangkan penyakit. Atas dasar ini, obat yang mampu menghilangkan penyakit ialah obat yang dijadikan Allah mampu mencegah terjadinya penyakit itu. Sedekah bisa mencegah penyakit sebagaimana juga bisa

${ }^{37}$ Imam Al-Baihaqi, Sunan Al-Baihaqi AlKubra, Makkah al-Mukarramah: Maktabah Dar alBaar, 1994/1414, juz 3, hal. 382 
menghilangkan penyakit dengan izin Allah. ${ }^{38}$

Dari titik tolak inilah seharusnya orang menaruh perhatian untuk suatu masalah penting. Yaitu agar seorang mukmin tidak bermualamah dengan Allah dalam bentuk coba-coba. Bila berhasil mendapatkan yang dikehendaki akan selalu dan konsisten melakukannya, sementara bila tidak berhasil akan melemah dan berhenti. Orang mukmin haruslah bermuamalah dengan Rabbnya dengan keyakinan yang kuat, kepercayaan dan tawakal yang benar, serta berbaik sangka kepada Allah.

\section{a. Mengobati Luka Nanah dengan Sedekah}

Ali bin Al-Hasan bin Syaqiq berkata, "Saya mendengar Ibnu Al-Mubarak ditanya seseorang, "Wahai Abu Abdurrahman, luka yang mengeluarkan nanah dari lututku sudah berlangsung selama tujuh tahun lamanya. Saya telah mengobatinya dengan berbagai obat dan bertanya kepada beberapa dokter, namun semuanya tak manjur". Ibnu Al-Mubarak berkata, "Pergilah ke suatu tempat di mana orang-orang memerlukan air di tempat itu, lalu galilah sumur di sana. Karena saya berharap di sana muncul air hingga lukamu berhenti. Orang itu melakukan yang disarankan oleh Ibnu Al-Mubarak dan penyakitnya pun sembuh". Al-Baihaqi berkata, "Berkenaan dengan hal serupa, ada sebuah cerita dari Syaikh kita, AlHakim Abu Abdullah. Wajahnya terluka dan berbagai pengobatan telah dicoba. Tetapi, sekitar setahun lamanya lukanya tak kunjung sembuh. Ia memohon kepada seorang guru, Imam Abu Utsman AshShabarani, agar mendoakannya sembuh di majelisnya pada hari Jumat. Sang guru mendoakannya dan sebagian orang mengamini. Pada hari Jumat berikutnya,

\footnotetext{
${ }^{38}$ Zaid bin Abdul Karim Az-Zaid, Rihlah Ash-Shadiqah
}

seorang wanita melempar selembar kertas kepadanya berisi perintah agar ia pulang. Ia bersungguh-sungguh berdoa untuk AlHakim bin Abdullah pada malam itu. Ia bermimpi melihat Rasulullah bersabda kepadanya, 'Katakan kepada Abu Abdullah agar ia memberikan air untuk kaum muslimin. Lalu saya membawa selembar kertas itu dan saya serahkan kepada AlHakim. Kemudian ia memerintahkan agar membangun saluran air di depan rumahnya. Seusai membangunnya, ia memerintahkan agar menumpahkan air ke saluran itu dan memberi es. Orang-orang kemudian memanfaatkan air itu untuk keperluan minum. Tidak berselang satu pekan lamanya, terlihatlah kesembuhan dan lukanya hilang. Wajahnya kembali seperti sediakala dan setelah kejadian itu ia hidup beberapa tahun. ${ }^{39}$

\section{b. Allah Menyembuhkan Kanker Karena Sedekah}

Kisah ini merupakan salah satu kisah masyhur yang sering diperbincangkan serta menjadi pelajaran dan.nasihat untuk semua orang. Pelaku kisah ini ialah seorang kaya dari kalangan pedagang sukses yang mengidap penyakit mengerikan yang tidak mampu ditahan. Ia pergi ke salah satu rumah sakit terkenal dan melakukan pemeriksaan intensif. Hasil pemeriksaan menunjukkan hasil yang sangat mengejutkan, terdapat kanker dalam tubuhnya dan persentase kesembuhannya amat tipis. Para dokter menyarankannya agar pergi ke luar negeri untuk berobat di sana.

Orang itu pun pergi ke salah satu negara serta melakukan berbagai pemeriksaan dan pengobatan sekali lagi, namun hasilnya sama seperti pemeriksaan awal. Para dokter menyarankannya agar menjalani operasi pemotongan beberapa bagian tubuh yang ditumbuhi kanker. Akan

\footnotetext{
${ }^{39}$ Muhammad Hamid bin Abdul Wahhab, AtTijarah Ar-Rabihah, tanpa keterangan.
} 
tetapi, pelaku kisah ini memohon kepada para dokter agar menangguhkan operasi tersebut beberapa saat, supaya ia dapat kembali ke negaranya untuk mengurus beberapa pekerjaannya dan berwasiat kepada para kerabat. Sebab, kemungkin ia tidak lagi dapat bertemu dengan mereka. Ia kembali ke negaranya, kemudian mengurus segala urusan bisnisnya, menulis surat wasiat, dan berpamitan kepada kerabatnya tanpa memberitahukan maksud kepergian sebenarnya. Pada suatu hari ketika ia hendak kembali ke rumahnya, ada wanita tua renta yang menarik perhatiannya. Wanita itu tengah berdiri di samping tempat pemotongan daging hewan. Ia terlihat memungut beberapa potongan tulang yang berjatuhan dari tempat pemotongan itu. Lelaki itu berhenti lalu mendekati wanita tua itu dan bertanya tentang kondisinya, mengapa ia mengumpulkan tulang-tulang itu? Wanita tua itu menjawab bahwa ia memiliki beberapa anak yang telah yatim dan miskin, sehingga mereka tidak memiliki uang untuk membeli daging. Karena itu, ia mengumpulkan tulang-tulang itu agar dapat dimasak untuk anak-anaknya sebagai pengganti daging. Lelaki itu merasa iba. Lantas ia mengeluarkan sejumlah uang yang banyak dan memberikannya kepada wanita itu serta meminta kepada pemotong hewan agar selalu mengirimkan sejumlah daging untuk keluarga wanita tua itu setiap pekannya. Ia juga memberikan uang dalam jumlah besar kepada pemotong hewan itu. Wanita tua itu berterima kasih kepada orang itu atas kebaikannya dan berdoa untuknya. Setelah itu, ia pulang. Lelaki itu kembali lagi ke luar negeri untuk menjalankan operasi bedah. Sebelum operasi dilakukan, para dokter kembali memeriksanya secara intensif dan hasilnya sangat mengejutkan. Sehingga, rona muka dokter berubah seraya marah. Dokter bertanya kepada orang itu, "Apa Anda pergi ke rumah sakit lain untuk berobat?"
Ia menjawab, "Tidak, saya tidak pergi ke rumah sakit lain." Dokter kembali bertanya, "Anda berdusta kepada saya, jujurlah kepada saya, apakah Anda pergi ke rumah sakit atau tidak?" Ia menjawab, "Saya bersumpah dengan nama Allah bahwa saya tidak berobat ke rumah sakit. Kenapa pertanyaan itu ditujukan kepada saya?" Setelah itu, dokter baru memberitahukan hasil pemeriksaannya... seraya berkata, "Pemeriksaan terbaru menunjukkan bahwa tidak ada lagi sisasisa kanker dalam tubuh Anda. Sekarang Anda berada dalam kondisi sehat." Tapi orang itu tidak memercayai keterangan dokter yang ia dengar. Tiba-tiba air matanya mengalir dari kedua matanya, kemudian bertany kepada dokter, "Apakah yang Anda katakan itu benar?" Dokter itu juga bersumpah dengan nama Allah mengenai hal itu, lantas memperlihatkan hasil pemeriksaannya. Ia memuji Allah lalu kembali ke negaranya dengan selamat dan sehat. Ia menceritakan kisah itu kepada keluarganya, dan keluarganya terkesima dengan apa yang telah mereka dengar. Ia pun berkata, "Allah menyembuhkan penyakitku karena doa wanita tua yang aku beri sedekah untuk anak-anaknya yang yatim itu."Ia pun berjanji kepada dirinya tantuk menjaga keluarga miskin tersebut hingga waktu yang dikehendaki Allah. Mahasuci Allah Yang Mahakuasa. ${ }^{40}$

\section{c. Batu Ginjal dan Sedekah}

Seorang ayah mengeluh karena sakit yang tiba-tiba tanpa diketahui penyebabnya. Ia tetap saja mengerang kesakitan karena sakitnya yang luar biasa. Anaknya membawanya ke dokter untuk mengetahui penyebab sakitnya itu, lalu dokter mulai memeriksa penyakitnya. Ternyata hasil pemeriksaan menunjukkan adanya batu dalam ginjalnya. Batu harus

\footnotetext{
${ }^{40}$ Hasan bin Ahmad Hammam, et al, Terapi Dengan Ibadah, Kartasura Solo, 2015, PT. Aqwam Media Profetika, hal. 448
} 
dikeluarkan melalui operasi bedah. Ayah dan anak tersebut selanjutnya pulang ke rumah untuk mempersiapkan operasi. Pada pagi harinya, anak tersebut pergi menuju tempat kerjanya yang baru sebulan dimasuki dan hari jitu ialah akhir bulan saat menerima gaji. Ia merasa senang sekalit menerima gajinya. Karena itu ialah gaji pertama yang ia dapatkan dari pekerjaan barunya. Saat pulang ke rumah, ia melihat seorang fakir yang berpenampilan buruk dan renta serta tampak kelelahan.

Anak itu mulai memperhatikan kondisi itu. Tiba-tiba ia menetapkan suatu tindakan dengan cepat, ia harus menyedekahkan seluruh gajinya yang baru diperoleh itu kepada Pengemis tersebut dengan niat agar Allah menyembuhkan penyakit ayahnya. Dan benar, ia mengeluarkan uang tersebut lalu memberikannya kepada pengemis tersebut lantas ia pulang ke rumah dan mengetuk pintu. Tiba-tiba ayahnya membuka pintu. Di wajahnya terlihat kebahagiaan dan kegembiraan. Kemudian ia berkata kepada anaknya, "Anakku, alhamdulillah, alhamdulillah, baru saja saya merasakan sakit yang luar biasa itu, lalu saya pergi ke kamar mandi untuk buang air hingga keluarlah batu tersebut. Sekarang saya merasa sangat lega sekali." Anak itu pun menangis karena bahagia dan ia pun memuji Allah. ${ }^{41}$

\section{Puasa Tinjauan Islam dan Sains}

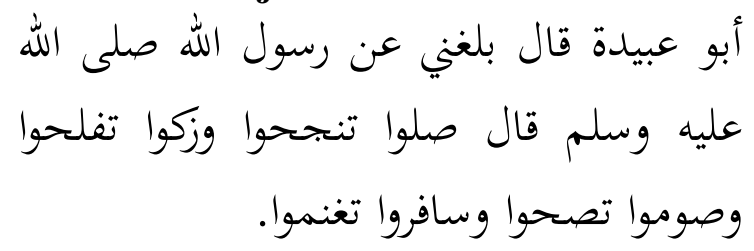

Dari Abu Ubaidah RA, dari Rasulullah SAW, bersabda, "Shalatlah kalian niscaya kalian akan sukses, berzakatlah kalian

\footnotetext{
${ }^{41}$ Kisah ini dituturkan oleh Sayyid Juwail, dinukil dari majalah Al- Mujtama'.
}

niscaya kalian akan beruntung, berpuasalah kalian niscaya kalian akan sehat dan bepergianlah kalian niscaya kalian akan memperoleh ghanimah". ${ }^{42}$

Selain itu, dunia medis juga telah mengakui fakta-fakta ilmiah tentang puasa. Make Vadon seorang ahli kesehatan Amerika menyatakan bahwa setiap manusia perlu berpuasa jika tidak sedang sakit, karena racun-racun makanan berkumpul dalam tubuh hingga menyebabkan orang sakit. Racun-racun itu membebani tubuh manusia dan mengurangi semangatnya dalam beraktivitas. Apabila tubuh dipuasakan maka bebannya akan berkurang dan racunracun itu akan melebur dengan sendirinya dan habis secara tuntas. Sebagaimana halnya puasa juga mampu memulihkan dan memperbarui sel-sel tubuh sehingga daya tubuh kembali pulih dan aktif seperti sedia kala.

Sementara itu, penerima hadiah Nobel di bidang kedokteran, Alexis Karel, menulis dalam bukunya yang berjudul Manusia yang Misterius, "Sungguh banyaknya makanan yang melimpah menyebabkan lumpuhnya satu fungsi penting yang berperan besar bagi keberlangsungan berbagai spesies hidup di permukaan bumi ini. Fungsi yang dimaksud ialah kemampuan beradaptasi terhadap keterbatasan makanan. Oleh karena itu, umat manusia hendaknya selalu berpuasa pada setiap masa."

Dr. Muhammad Sa'id As-Suyuthy mengatakan, "Puasa mampu mencegah terjadinya penimbunan zat-zat beracun yang berbahaya bagi tubuh, seperti asam karbol, asam fosfat amunia, zat-zat asam, serta zat-zat garam yang berbahaya lainnya. Begitu juga puasa dapat mencegah

${ }^{42}$ Ar-Rabi' bin Habib bin Umar al-Bashari alAzdi, Musnad ar-Rabi' bin Habib, Beirut: Dar alHikmah Maktabah al-Istiqamah, 1415, juz 1, hal. 122 
tubuh dari penyakit encok dan peradangan pada persendian tulang (rematik) serta mencegah dari pembentukan sampah di ginjal.

Dr. Ibrahim Arrawy menegaskan bahwa puasa mampu meningkatkan stimulus sel-sel otak sehingga aktivitasnya bertambah beberapa kali lipat. Hal itu dikarenakan berhentinya aktivitas alat pencernaan pada saat berpuasa sehingga darah mengalir deras ke jaringan otak, mensubsidi lilitan otak, dan mensuplainya dengan berbagai nutrisi terbaik bagi kebutuhan aktivitasnya. Hal ini bisa dijadikan sebagai penjelasan bagi banyaknya para pemikir yang menjadikan puasa sebagai cara mereka untuk meningkatkan kemampuan dan kapasitas otak mereka. ${ }^{43}$

Penelitian kedokteran yang terdiri dari para pakar medis dari berbagai golongan dan agama, menetapkan bahwa berlebih-lebihan dalam mengkofisumsi makanan bisa beresiko amat fatal. Karena, hal itu bisa berakibat timbulnva penvakit bagi kehidupan manusia. Walau pada dasarnva manusia mampu mengurangi frekuensi kebutuhan makanan, namun menurut frekuensi idealnya, kebutuhan itu akan semakin bertambah. Itulah alasannya mengapa manusia terkena penyakit yang bermula dari proses pencernaan makanan.

Hal ini berdampak pada timbulnya kekuatan jantung dan pembuluh darah yang berakibat meningkatnya tekanan darah dan terhentinya campuran darah nanah. Kemudian hal ini berakibat tambahnya tekanan darah yang kemudian menyebabkan penyakit (kencing manis). Tak ada jalan lain untuk mengatasi penyakit tersebut kecuali dengan mengantisipasi timbulnya gejala-gejala yang disebabkannya. Lapar pada saat-

\footnotetext{
${ }^{43}$ Hasan bin Ahmad Hammam, et al, Terapi Dengan Ibadah, penerbit Aqwam Jembatan Ilmu, cet. 8 2015, Solo, 359-370.
}

saat tertentu pada organ tubuh menjadi keharusan, agar kiranya proses pencernaan bagian dalam bisa bergerak membasmi sel-sel kecil. Dengan begitu, fisik akan kembali normal setelah terjadinya pembentukan sel-sel (baru) yang sehat dan kuat.

Tidak asing lagi jika studi-studi ilmiah baik di belahan Barat dan Timur menguatkan suatu pernyataan bahwa puasa adalah suatu sikap antisipatif. Ia berfungsi sebagai terapi dari bahaya penyakitpenyakit kontemporer (kekinian). Lebih dari itu, sebagai pembaharu jaringanjaringan sel di samping mampu mennghilangkan unsur-unsur penyakit yang tidak dibutuhkan tubuh lagi.

Puasa dapat memberi ruang bagi perut dan usus untuk menyaring makanan. Karenanya, ia bisa meredakan "aktivitasaktivitas" kotoran dalam perut dan usus. Kondisi seperti ini mampu memberi ruang yang tepat untuk mengobati luka-luka dengan adanya selaput lendir. Kemudian daya serap itu terhenti dari usus. Pada akhirnya asam amonia tidak sampai pada jantung, glukosa, ataupun zat garam.

Atas dasar inilah, sel-sel jantung tidak dapat melakukan pembentukan struktur glikogen, protein-protein atau kolesterol, karena tidak adanya hubungan yang terbentuk. Itulah hasil dari kekosongan usus dari berbagai makanan. Karenanya, penyerapan menjadi tersumbat. Dengan demikian, ibadah puasa memberikan ruang bagi sel-sel jantung untuk menghindari terjadinya lemak-lemak yang kadangkala meresap di dalamnya.

Puasa juga berguna sebagai terapi penyakit kencing manis. Dalam satu penelitian, rata-rata kadar gula dalam darah seseorang mengalami penurunan dengan dilakukannya ibadah puasa. Di Amerika telah ditemukan sebuah kesimpulan dari kajian-kajian ilmiah yang membahas kekuatan puasa dalam menjaga sekaligus 
mengobati seseorang dari bahaya kencing manis. ${ }^{44}$

Di Jerman, pernah didirikan pemondokan untuk pengobatan. Pasien di dalamnya tidak sekadar mereka yang menderita sakit, masyarakat sehat pun dengan serta merta ikut berobat. Resep yang diberikan adalah "semua tamu diwajibkan untuk menahan makan dan minum" lebih dari 10 jam namun kurang dari 20 jam setiap hari. Di samping itu, juga diberikan resep berupa untuk melakukan aktivitas-aktivitas yang cukup ringan. Program ini berlaku tidak kurang dari tiga atau empat minggu. Ia dilakukan secara kontinu tanpa putus dalam rentang masa itu. Artinya, program ini ternyata persis seperti konsep puasa menurut ajaran Islam. $^{45}$

Rusia, sebuah negara komunis yang tidak mengakui agama-agama samawi, secara keras menyerang Islam dan ajaranajarannya, termasuk juga "puasa". Namun, pada akhirnya negara itu mengakui adanya faedah-faedah puasa bagi manusia. Tak pelak, majalah "Al-Aghdziah" yang terbit di Rusia mempublikasikan berita itu. Secara harfiah dapat dibaca dalam terjemahan berikut ini,

"Pada akhirnya mereka mengakui komentar yang ada dalam buku Prof. Nicholev Wanzlop bahwa "lapar dapat berguna sebagai terapi kesehatan". Sebuah"keharusan bagi setiap individu di dalam komunal negara besar, agar kesehatan fisiknya bisa terkontrol, hanyalah dengan cara membuang kotorankotoran yang mengandung zat beracun dalam tubuh. Prakteknya yaitu dengan menahan lapar pada periode-periode tertentu secara sempurna dengan

\footnotetext{
${ }^{44}$ Abdush-Shamad, Muhammad Kamil, Mukjizat Ilmiah dalam Al-Quran, Jakarta, Akbar Media Eka Sarana, 2002, hal. 305.

45Abdurrazzaq Naufal, Limun wa Bayaanun min Aayaati Al-Qur'an ${ }^{\text {(Majalah }}$ Al-Wa'i al-lslami, edisi Juni
}

meninggalkan mengkon- sumsi makanan pada pentang masa tidak kurang dari tiga minggu dan tidak lebih dari empat minggu." $" 46$

Barangkali rumah sakit international paling populer sekarang adalah rumah sakit Dr. Hendrik Lehmann yang berada di Sixonia yang mempunyai adagium sangat terkenal: "Puasa sebagai langkah pengobatan". Sementara itu, rumah sakitrumah sakit lain kian berkembang dengan menganut pola yang diterapkan rumah sakit di atas.

Penemuan medis juga memperkukuh ketegasan bahwa puasa bisa melindungi diri dari banyak penyakit, juga dapat mengurangi lemak-lemak dalam tubuh yang berarti juga mengurangi kadar kolesterol. Yakni, unsur yang mengendap di atas pembuluh-pembuluh darah yang berakibat menjadi keras. Di samping itu, menyebabkan terjadinya pembekuan darah di dalam pembuluh-pembuluh jantung dan otak.

Karena itu, puasa dari satu sisi berguna bagi peredaran jantung dan pada sisi lain berguna bagi organ-organ tubuh, seperti pelangsingan badan. Sementara penurunan kadar volume lemak yang membalut di seputar jantung, akan menjadikan daya aktivitas tubuh semakin baik.

Juga sebagaimana penemuan medis, puasa menimbulkan daya kekuatan (daya dobrak) yang sangat Juar biasa dalam membasmi semacam virus-virus kecil, dan sekaligus mencegah terjadinya elaborasi unsur-unsur zat kapur. Jika telah terjadi, maka cara terapinya dengan harus sedikit demi sedikit.

Dalam hal ini, Dr. Robert Bertolio berkata, 'Tiada syak lagi bahwa puasa sebenarnya sebagai media aktivitasaktivitas yang mampu menyingkirkan

\footnotetext{
${ }^{46}$ Majalah Al-Aghdziyah ar-Rusiyah, terbit di Moskow edisi 01 tahun 1976.
} 
kuman-kuman dalam tubuh, di antaranya jenis kuman-kuman "zuhri" yang memiliki kandungan unsur-unsur yang bisa merusak sel-sel. Dengan menjalankan puasa, struktur sel-sel yang rusak tadi bisa menjadi tumbuh kembali.

Dr. Blair Charneber berpendapat bahwa puasa satu bulan penuh dalam satu tahun bak pondasi kehidupan, dan ibarat akar masa remaja. Hal ini lebih mengacu pada faedah-faedah yang utama, sebab mampu meng-genzhne-kan penyakitpenyakit dalam organ tubuh manusia. Maka, puasa dalam semua aspeknya adalah bagus. $^{47}$

Teks ayat 184 surah al-Baqarah di atas dengan kata "al- khair" memberikan pengertian yang sangat umum. Dengan demikian, mustahil seorang pakar mampu mungupas sedetail-detailnya isi kandungan ayat itu. Rahasia ilmiah yang sangat menakjubkan tentang hikmah puasa dan ayat-ayat yang menjelaskannya, telah membuka tabir yang kemudian menjadi inspirator kajian-kajian ilmiah hingga sekarang.

\section{Kesimpulan}

Islam adalah agama yang mengajarkan kesucian dan kebersihan kepada umatnya baik jasmani maupun rohani. Secara fisik islam mengajarkan kebersihan melalui perintah membersihkan diri dari kotoran fisik berupa najis dan hadats dengan cara berwudhu dan mandi. Secara rohani islam mengajarkan kepada umatnya untuk senantiasa membersihkan jiwa dari kotoran-kotan dosa melalui ibadah. Baik itu berupa ibadah shalat, puasa, sedekah, zakat, umrah, haji dan lainnya. Ibadah berfungsi mengembalikan jiwa pada kesucian, fitrah dan kondisi netral. Kesucian jiwa akan menghadirkan

\footnotetext{
${ }^{47}$ Abdush-Shamad, Muhammad Kamil, Mukjizat Ilmiah dalam Al-Quran, Jakarta, Akbar Media Eka Sarana, 2002, hal. 308
}

ketenangan jiwa. Ketenangan jiwa inilah yang memperbaiki sistem kekebalan tubuh manusia. Meningkatkan imunitas dan antibodi. Hal ini dibuktikan berbagai riset dan kajian ilmiah. Diantaranya yang dilakukan lembaga riset Islam di Amerika. Hasil penelitian menyatakan bahwa ketenangan jiwa yang dihasilkan dengan shalat berdampak positif terhadap sistem kekebalan tubuh (antibodi). Sehingga dapat mempercepat proses penyembuhan, khususnya beberapa penyakit yang disebabkan oleh kelainan antibodi, seperti radang persendian, reumatik dan penyakit lupus. Hasil riset juga menerangkan bahwa standar kesembuhan penyakit terjadi lebih cepat bagi para pasien yang senantiasa rutin melaksanakan ibadah. Karena ibadah dapat mengisi hati dengan keimanan, optimisme, ketenangan jiwa, dan ketentraman. Dengan demikian sistem kekebalan tubuh akan lebih aktif dan bertambah kuat dalam melindungi tubuh.

\section{DAFTAR PUSTAKA}

Azdi, Ar-Rabi' bin Habib bin Umar alAzdi al-Bashari, Al-, Musnad arRabi' bin Habib, Beirut: Dar alHikmah Maktabah al-Istiqamah, $1415 \mathrm{H}$.

Baihaqi, Imam Al-, Sunan Al-Baihaqi AlKubra, Makkah al-Mukarramah: Maktabah Dar al-Baar, 1994 M/1414 H.

Bukhari, Muhammad bin Ismail bin Ibrahim bin Al-Mughirah Al-, AlJami' Ash-Shahih, Kairo, Dar AsySya'b, Cet. I, 1987.

Hammam, Hasan bin Ahmad, et al, Terapi Dengan Ibadah, Kartasura Solo, 2015 M, PT. Aqwam Media Profetika. 
Hanbali, Ahmad bin Hanbal Abu Abdullah, Musnad Al-Imam Ahmad bin Hanbal, Kairo, Muassasah Qurthubah.

Iyadh, Al-Qadhi, Ikmal al-Muallim Syarh Shahih Muslim, tanpa keterangan.

Jauziyah, Abu Abdullah Ibn Al-Qayyim, I'lam Al-Muwaqi'in 'an Rabb Al'Alamin, Dar Al-Jail, Beirut, 1973.

Jibrin, Abdullah bin Abdurrahman Al-, Syarah Umdatul Ahkam, tanpa keterangan.

Kamil, Abdush-Shamad Muhammad, Mukjizat Ilmiah Dalam Al-Quran, Jakarta, Akbar Media Eka Sarana, 2002.

Khauly, Hilmi Habib al-, Al-Islaam wa AlWiqaayatu Min Ba'dhi As-Sarathaani, dimuat Majalah Al-'Arabie, Januari, 1985.

Majalah Al-Aghdziyah ar-Rusiyah, terbit di Moskow edisi 01 tahun 1976.

Naisaburi, Imam al-Hakim An-, alMustadrak 'Ala Ash-Shahihaini, Beirut: dar Al-Kutub Al-Ilmiyah, 1990/1411.
Naufal, Abdurrazzaq, Limun wa Bayaanun min Aayaati Al-Qur'an, Majalah Al-Wa'i al1slami, ${ }^{\text {edisi Juni } 1984 .}$

Sayyid Juwail, majalah Al- Mujtama'.

Syarif, Adnan Asy-, Min Ilmi Al-Thib AlQurani, 2001, Beirut, Lebanon, Dar Al-Ilmi li Al-Malayin.

Syukur, M. Amin, Zikir Menyembuhkan Kankerku, penerbit Hikmah.

Tirmidzi, Imam At-, al-Jami' ash-Shahih Sunan At-Tirmidzi, Beirut, Dar Ihya' at-Turats al-Arabi.

Tirmidzi, Muhammad bin Isa Abu Isa at-, Al-Jami' Ash-Shahih Sunan AtTirmidzi, Dar Ihya' At-turats AlAraby, Beirut, Juz 4, hal. 462.

Wahhab, Muhammad Hamid bin Abdul, At-Tijarah Ar-Rabihah, tanpa keterangan.

Zaid bin Abdul Karim Az-Zaid, Rihlah Ash-Shadiqah. 
